\title{
УДК 007:304:655
}

\section{Fiialka S. B.}

PhD in Social Communications Sciences, National Technical University of Ukraine «lgor Sikorsky Kyiv Polytechnic Institute», Kyiv

\section{SOCIO-COMMUNICATIVE APPROACH TO STUDYING OF THE EDUCATIONAL LITERATURE}

The educational literature is investigated as a social phenomenon and the multifaceted process of its creation and functioning in the broad context of social relations is inscribed. The role of subjects of communicative interaction in the creation of the educational literature is defined: the Ministry of Education and Science of Ukraine, the author who prepared the work, the editor (editorial and publishing group), teachers who use the educational literature in the educational process, students and adults who help students prepare their homework. The opinions of teachers and students about the educational literature were studied and general directions of editorial work on harmonization of interests of direct consumers of the educational literature and society as a whole were generalized. It is proved that modern textbooks should contain images of people with disabilities and make them part of the picture of the world that education forms in the minds of children; change the image of the elderly; if possible, equalize the social roles of men and women. Working on the educational literature, the editor should act in several ways: to take into account the organizational aspect of the educational book publishing; to check the conformity of the filling of the educational literature with the existing system of standards: state the educational standards, curriculum, publishing standards; to ensure elimination of linguistic, logical, factual, compositional and other mistakes; take into account the features and needs of communicants (students and teachers); to ensure that the book performs the socio-communicative functions; consider the educational literature as a social system in its interaction with other subsystems of society; take into account the economic, political, social changes taking place in society, the society's reactions to changes in approaches to the presentation of the material in the educational literature.

Keywords: socio-communicative approach, the educational literature, author, editor, reader, publishing, information society. 
Фіалка С. Б.

канд. наук із соц. комунікацій, доц. кафедри видавничої справи та редагування Видавничо-поліграфічного інституту, КПІ ім. Ігоря Сікорського, м. Київ, Україна

\section{СОЦАЛЬНО-КОМУНІКАЦЙНИЙ ПІДХІД ДО ВИВЧЕННЯ НАВЧАЛЬНОЇ ЛІТЕРАТУРИ}

Досліджено навчальну літературу як соиіальний феномен та виведено багатогранний процес ї̈ створення й функціонування в иирокий контекст сочіальних зв'язків. Визначено роль суб'єктів комунікативної взаємодії у створенні навчальної літератури: Міністерства освіти і науки України, автора, який підготував твір, редактора (редакиійно-видавничої груnи), педагогів, котрі використовують навчальні видання в освітньому процесі, самих учнів (студентів), а також дорослих, які допомагають учням у підготовиі домашніх завдань. Наведено зріз думок педагогів та учнів щзодо навчальних видань та узагальнено напрями редакторської роботи стосовно гармонізації інтересів як безпосередніх споживачів навчальної літератури, так і всього суспільства. Аргументовано потребу ввести в сучасні підручники образи людей з інвалідністю і зробити ӥх частиною картини світу, яку освіта формує в дітей; змінити образ людей похилого віку; по можливості зрівняти сочіальні ролі чоловіків і жінок. Працюючи з навчальною літературою, редактор має діяти в кількох площчинах: зважати на організаційний аспект навчального книговидання; перевіряти відповідність наповнення навчальних видань наявній системі нормативів: державним освітнім стандартам, навчальним програмам, видавничим стандартам; забезпечувати усунення мовностилістичних, логічних, фактичних, композиційних та інших помилок; ураховувати особливості та потреби комунікантів (цільової аудиторії), при цььому як учнів (студентів), так і вчителів (викладачів); забезпечувати виконання виданням соціокомунікативних функиій; розглядати навчальну книгу як сочіальну систему в ї̈ взаємодії з іншими підсистемами суспільства; ураховувати економічні, політичні, соціальні зміни, щуо відбуваються в соиіумі, реакиї суспільства на зміни в підходах до подання матеріалу в навчальних виданнях.

Ключові слова: соціокомунікативний підхід, навчальна література, автор, редактор, читач, видавнича справа, інформаційне суспільство.

Formulation of the problem. The relevance of the study is due to the intensification of the information society formation, which we understand, firstly, as a society formed under the influence of globalization processes and information and communication technologies; and secondly, it is a society 
in which the main condition of well-being of each individual and the state as a whole is the level of knowledge, ability to work with information; thirdly, it is a global society where there is no limit to the exchange of information. The educational literature plays an essential role in the formation of the information society, because it is intended to promote intellectualization, the development of ideological orientations of children and young adults, which forms the basis for knowledge acquisition, is an «accumulator», storing actual social experience. Such literature is designed to form the knowledge, skills, rational and emotional reflection of the world for the reader, his ideological position, aesthetic and ethical preferences. Thanks to the educational literature, readers become active subjects of communication, learn not to passively perceive the information contained in the book, but to encourage the author and editor to take into account their readership interests and tastes. However, the essential problem of our time is the imperfection of the very procedure of the educational literature publishing, contradictions between the goals of authors, teachers, the educational officials, students themselves. At the same time, the need to study the educational literature from the point of view of socio-communicative approach, in particular its functioning, its influence on society and its dependence on society, becomes increasingly relevant.

Analysis of previous researches. E. Ogar substantiated the utility of using socio-communicative approach and described its possibilities, in particular, the interdisciplinary synergetic nature, the comprehensiveness of the analysis of book communication in interaction with other modern communicative models [1]. According to the researcher, the potential of this approach is to comprehensively analyze the issues of the book as part of the system of social communications: from its creation, editorial and publishing work, perception, role in society, as well as interaction with other mass media. The main criterion for the effectiveness of the book E. Ogar considers its functionality, namely the ability to perform the tasks assigned to it [1].

Ya. Pryhoda applied a socio-communicative approach to the study of the activities of publishing houses, in particular, the object of her scientific studies was the publishing and informational environment, publishing teams, communications between them, communication space [2].

O. Trischuk expounded in detail the essence of the socio-communicative approach, which «involves understanding editorial and publishing process as a set of interrelated social (organizational, managerial, creative, production, information and marketing) sequential actions aimed at the production, 
implementation in the information and communication circulation such publishing product that satisfies the reader's needs of different social groups, is a mean of transferring public values, that promotes the formation of a communicative community». As a characteristic feature of socio-communicative approach, the researcher determines the unity of such elements as communicators (authors, editors, readers), publishing products, information and communication space [3].

$\mathrm{N}$. Balandina studied the nature of the text and educational discourse. The researcher proved that the delimitation of these concepts is methodologically justified, since «the text is a static formation with a stable and completed form, the result of activity that, under certain conditions, leads to another discursive activity, which manifests the dynamic nature of the educational process that continues in space and time. The logic of the deployment of educational discourse initially lies around constant text information (content and formal), which, accordingly, serves as the basis for the creative interpretation of the text by subjects of knowledge» [4].

A. Gabidullina analyzed the educational and pedagogical discourse, considering the role of the educational literature in a specially organized educational communication. [5]. In this case, E. Johnsen noted that the educational literature should be analyzed simultaneously in many contexts, namely scientific, pedagogical, political, moral, economic, etc. [6].

The educational literature is always in the dynamics, is constantly discussed, updated under the influence of scientific achievements, society, the requirements of the educational officials, and its perception is determined by the opportunities of the students and by the teacher's skills [7]. Meanwhile, the value of the educational literature depends also on how the teacher interacts with his students, relying on a book [8].

The purpose of the work. Socio-communicative essence of the educational literature remains poorly studied, therefore, there is a need to thoroughly investigate the educational literature as a social phenomenon and to bring out the multifaceted process of their creation and functioning in the broad context of social relations. This determined the purpose of our paper.

Results. The subjects of communicative interaction in the creation of the educational literature are the Ministry of Education and Science of Ukraine with its normative system, the author who prepared the work, the editor (editorial and publishing group), teachers who use editions in the educational process, as well as the students themselves. Additionally, the content of the educational literature can be critically analyzed by the adults, 
who help pupils in the preparation of homework and are interested in the content of textbooks, which are used by their children, grandchildren, et al.

However, the main subjects in the educational-pedagogical discourse are two «subjects of knowledge» - a teacher and a student. The task of the editor and the author is to provide a basis for the interaction of these subjects, the compliance of the edition with the requirements of both the education system and the needs and capabilities of the readers.

Speaking about the role of the Ministry of Education and Science of Ukraine, now efforts are being made to clear the system of peer review of the educational literature from subjectivism and conflict of interests; the current system of competitive selection of textbooks takes into account the opinions of teachers, and schools have the opportunity to choose textbooks to teach children on their own. However, despite all these measures, some textbooks contain errors, inaccuracies, outdated concepts, and so on. In particular, in this regard, posts in the communities of educators and parents in social networks that are actively commented on are constantly appearing.

In this study, we will try to identify problem areas in the educational literature publishing for each subject of knowledge and generalize the directions of editorial work on harmonizing the interests of both these subjects and the interests of the entire society.

During August, 2018, a survey on the quality of the educational literature was conducted in the Facebook group «Learning: Community of Educators». The post was commented by 198 schoolteachers and 94 teachers of higher education establishments. Among the most common disadvantages of the educational literature, they called it lag behind the pace and demands of social development; lack of motivational component; partial inconsistency with the program; availability of outdated definitions, terminological inaccuracies, actual errors; low didactic and linguistic culture of texts; excessive amount of tasks and lack of communication between the theory and the practice; non-compliance of the volume of the educational material and the time allocated for its assimilation; the non-differentiation of the material, which is mandatory for memorization, and that is intended only for familiarization; overload with secondary information; excessive difficulty or unjustified simplification of the material; insufficient consideration of students' interests and age characteristics; lack of group tasks; lack of interactivity; the use of an irrelevant, communicatively unjustified vocabulary; the presence of stereotypes and hate speech; inconsistency with sanitary norms; late delivery of textbooks. We would like to emphasize that the lack of a 
textbook is an additional stress for the teacher, who, taking into account the problems with the purchase of equipment and the beginning of the educational reform, is under a heavyweight psychological pressure.

At the same time, an oral survey of 150 students of the Polytechnic Lyceum of NTUU «KPI» (grades 7-11) was conducted, which highlighted such flaws in the educational literature: uninteresting statements, uninteresting tasks, too complex tasks, poor quality of illustrations, and the presence of a large number of unfamiliar words. That is, the success of the interaction between the educational literature and the student is determined not only by the pedagogical intentions embodied in the book, but also the ability of the book to generate interest, the presence of a motivational component, in particular the confirmation of the usefulness of the provided information in real life.

Socio-communicative interaction of the educational literature and the student takes place in the form of dialogue with the reader, as well as the targeted influence on the addressee (transfer of knowledge, technological skills, cultural heritage, value orientations, behavioral patterns, ideological, ethical and aesthetic positions). In such a systematic vision of the nature of the educational book is the key to the effectiveness of all processes associated with its creation, editorial work, printing and distribution.

Also, 40 parents of lyceum students were interviewed, who noted, first and foremost, such disadvantages of the educational literature as high cost, poor quality of printed reproduction, the availability of outdated textbooks with out-of-date information, and an overly complicated presentation. Like teachers, parents also pointed out the problem of delayed delivery of new textbooks. In addition, they proposed to use the foreign educational textbook adapted to Ukrainian realities in the educational process.

If we talk about the social significance of the educational literature, it is potentially capable to cause profound changes in the consciousness, the behavior of the reader, rebuilding its inner world, purposefully forming moral qualities, raising the level of culture and professional training, and developing individual skills.

The using of the educational literature is regulated by the cultural atmosphere in society. It is important that the educational books do not contain any discriminatory subtext; the content of the textbooks contribute to the formation of patriotism, love and respect to Ukraine, its people, language, family values, tolerant attitude to every person, regardless of gender, ethnic, religious, cultural membership or other features; bring up 
a person with developed critical thinking, ready for effective intercultural interaction. Educational information should be provided in the form of simulated practical situations, which would take into account the psychological characteristics of students. After reading, for example, the math problem, the student, along with its substantive content, perceives and the hidden "social context»: how the people mentioned in the task act, what they are engaged in, what their aspirations are, what their roles in society are, and so on.

In this context, it's worth mentioning the anti-discrimination expertise of textbooks for first-graders, initiated by the Institute of Family. On the one hand, according to some experts, the recommendations may distort the representation of children about sex, family, and paternity. On the other hand, in the textbooks were found unacceptable phrases like "Negroes», «Jews», «Gypsies». It was also found that in the textbooks there are almost no characters representing people with disabilities, and elderly people are portrayed as extremely weak and helpless. The books that depict boys or adult men and women in stereotyped roles, especially in relation to «male» and «female» work, also contain the signs of discrimination [9]. It is therefore necessary to introduce the images of people with disabilities in modern textbooks; change the perception of the elderly; if possible, equalize the social roles of men and women [10].

The key to evaluating of the educational literature should be the socio-functional quality of the text. Created with a completely pragmatic purpose, the educational book has to perform certain socio-communicative functions: information and cognitive (information transmission), the formation of a worldview (ideological positions), integrative (connection with other disciplines and publications), consolidation and verification of knowledge (didactic elements), organization of the process of reading and memorizing (the organization of the material), motivational (motivating certain actions), heuristic (comprehensive development of personality), literary-personal (formation of the speech culture of the reader), visual (illustrations) and aesthetic (the attractiveness of the book for contemplation). Implementing isolated functions as a system, the educational publications acquire their typological features: they contribute to the formation of the informational, linguistic and universal culture of a student, the developing of his or her creative abilities, the upbringing of scientific world outlook, tolerance, the principles of civilized coexistence, and respect for national cultural values. Hence, knowledge becomes an instrument of 
thinking, motivates an independent comprehension of reality, becomes a potential for self-development. Socio-communicative functions of the educational literature undergo changes with the development of society, because the book functions in the society and with it undergo all evolutionary and revolutionary changes.

In the period of the reform of the educational system, the creation of the educational literature of an innovative type, which would give students the opportunity to form their own trajectory of obtaining knowledge, were interactive, ensured the development of creative potential and mobility during training, becomes of paramount importance.

A professional communicator (namely, the editor) should take into account the interests of all participants in the communicative interaction in the field of the educational literature publishing. For this, he or she needs not only to be able to process the author's original from the language-lysical, logical, compositional, factual views, but also:

- to orient in modern social processes;

- to understand deeply the processes taking place in the education system;

- to understand the normative requirements for the educational literature and keep up to date with them;

- to update their professional knowledge;

- to interact with the authors at the stage of collecting all elements of the educational book;

- to study and implement the best foreign experience in the field of the educational literature publishing;

- to cooperate with practicing teachers;

- to search for the possibility of coexistence of traditional publishing and the latest digital format for the book;

- to know the age-old psychology of readers;

- to maintain feedback with teachers and students;

- to have a broad erudition, keep abreast of the latest scientific achievements;

- to have a critical thinking;

- to be the participant of world network communities in the field of science, education and editing;

- to know modern innovative pedagogical techniques, to show «intellectual initiative» in cooperation with the author;

- to have leadership skills, be responsible for decision making. 
Conclusions. Creation of the educational literature is a complex multifaceted process, which, on the one hand, is determined by state educational standards and methodological recommendations, and on the other hand, it depends on the author's scientific and teaching experience, his or her outlook, and the professionalism of the editor.

The editor should take into account the interests of all participants in socio-communicative interaction: officials, students, authors, teachers, parents, society as a whole. Therefore, working on the educational literature, the editor should act in several ways: to take into account the organizational aspect of the educational book publishing; to check the conformity of the filling of the educational publications with the existing system of standards: state educational standards, curriculum, publishing standards; to ensure elimination of linguistic, logical, factual, compositional and other mistakes; take into account the features and needs of communicants (students and teachers); to ensure the implementation of the publication of socio-communicative functions; consider the educational literature as a social system in its interaction with other subsystems of society; take into account the economic, political, social changes taking place in society, the society's reactions to changes in approaches to the presentation of the material in the educational literature.

\section{СПИСОК ВИКОРИСТАНОЇ ЛІТЕРАТУРИ}

1. Огар E. I. Соціокомунікативний підхід у сучасних книгоорієнтованих дослідженнях // Наук. зап Укр. акад. друкарства. 2014. № 4. С. 160-165.

2. Прихода Я. В. Соціокомунікаційний підхід до вивчення діяльності видавництв // Обрії друкарства. 2015. № 1. С. 138-143.

3. Тріщук О. В. Соціокомунікативний підхід до дослідження редакційновидавничого процесу // Обрї̈ друкарства. 2018. № 1. С. 218-230.

4. Баландіна Н. Ф. Навчальний текст і навчальний дискурс: ключі до розуміння // Вісн. КНЛ. 2017. № 2. С. 92-97.

5. Габідулліна А. Р. Навчально-педагогічний дискурс як лінгвістичний феномен Габідулліна [Електронний ресурс]. - URL: https://movoznavstvo. org.ua/index.php?option=com_attachments\&task=download\&id=398 (дата звернення: 01.09.2018).

6. Johnsen, E. Textbook knowledge: Introduction to genres and use // Lærebokkunnskap: Innføring i sjanger og bruk. Oslo: Tano Aschehoug, 1995. Pp. 45-65. 
7. Santos, D. Investigating the textbook in situated practices: What goes on in literacy events mediated by the EFL textbook? // Ensino de língua inglesa: Contribuições da linguística aplicada. 2008. Vol. 3. Pp. 143-173.

8. Walker, $R$. Textbook pedagogy: A sociological analysis of effective teaching and learning / R. Walker \& M. Horsley // Effective schools / D. McInerney, M. Dowson, \& S. Etten (Eds.). - Greenwich, CT: Information Age Publishing, 2006. Pp. 105-133.

9. $М О Н$ пояснює, для чого потрібна антидискримінаційна експертиза підручників [Електронний ресурс]. - URL: https://www.kmu.gov. ua/ua/news/mon-poyasnyuye-dlya-chogo-potribna-antidiskriminacijnaekspertiza-pidruchnikiv (дата звернення: 01.09.2018).

10. Мильчин А. Э. Новый общий курс редактирования (в порядке обсуждения) / А. Э. Мильчин // Книга: исследования и материалы : сб. 79. - М.: Терра-Книжный клуб, 2001. - С. 317-327.

\section{REFERENCES}

1. Ogar. E. (2014). Sociokomunikatyvnyj pidhid u suchasnyh knygooriyentovanyh doslidzhennyah [Socio-communicative approach in modern book-oriented research]. Naukovi zapysky Ukrayinskooyi akademiyi drukarstva, Vol. 4, pp. 160-165.

2. Pry'hoda, Ya. (2015). Sociokomunikacijnyj pidhid do vyvchennya diyalnosti vydavnycztv [Socio-communicative approach to the study of the activities of publishing houses]. Obriyi drukarstva, Vol. 1, pp. 138-143.

3. Trischuk, O. (2018). Sociokomunikatyvnyj pidhid do doslidzhennya redakcijno-vydavnychogo procesu [Socio-communicative approach to the study of the editorial and publishing process]. Obriyi drukarstva, Vol. 1, pp. 218-230.

4. Balandina, N. (2017). Navchalnyj tekst i navchalnyj dyskurs: klyuchi do rozuminnya [Educational text and educational discourse: the keys to understanding]. Visnyk KNL, Vol. 2, pp. 92-97.

5. Gabidullina, A. (2018). Navchalno-pedagogichnyj dyskurs yak lingvistychnyj fenomen [Educational-pedagogical discourse as a linguistic phenomenon], available at: https://movoznavstvo.org.ua/index.php?option=com_attachments\&task=download\&id=398 (accessed 1 September 2018).

6. Johnsen, E. (1995). Textbook knowledge: Introduction to genres and use. Lærebokkunnskap: Innføring i sjanger og bruk. Oslo: Tano Aschehoug, pp. $45-65$. 
7. Santos, D. (2008). Investigating the textbook in situated practices: What goes on in literacy events mediated by the EFL textbook? Ensino de língua inglesa: Contribuições da linguística aplicada, Vol. 3, pp. 143-173.

8. Walker, R., \& Horsley, M. (2006). Textbook Pedagogy: A Sociocultural Analysis of Effective Teaching. In D. McInerney, M. Dowson, \& S. Van Etten (Eds.), Effective Schools, Research on Sociocultural Influences on Motivation and Learning (Vol. 6, pp. 105-133). Greenwich: Information Age Publishing.

9. MON poyasnyuye, dlya chogo potribna antydyskryminacijna ekspertyza pidruchnykiv [MES explains why an anti-discrimination examination of textbooks is required], available at: https://www.kmu.gov.ua/ua/news/ mon-poyasnyuye-dlya-chogo-potribna-antidiskriminacijna-ekspertiza-pidruchnikiv (accessed 1 September 2018).

10. Mylchyn A. (2001). Novij obshhyj kurs redaktyrovanyya (v poryadke obsuzhdenyya) [New general editing course (under discussion)]. In Knyga: yssledovanyya y materyali (Vol. 75, pp. 317-127). Moskow: Terra-Knyzhnij klub.

Стаття надійшла до редакиії 02.09.2018. Received 02.09.2018 